Academic City University College - Accra Ghana

Society for Multidisciplinary \& Advanced Research Techniques (SMART) Africa

Tony Blair Institute for Global Change

FAIR Forward - Artificial Intelligence for All - Deutsche Gesellschaft für Internationale Zusammenarbeit (GIZ) GmbH

Accra Bespoke Multidisciplinary Innovations Conference (ABMIC)

\title{
Improvement on the Growth Performance of Parkia biglobosa Seedlings (African Locust Bean Tree) Using Inorganic Fertilizers
}

* Kareem, I. A. \& Salaudeen, R. O.

Department of Plant Science \& Biotechnology,

Faculty of Science,

Adekunle Ajasin University,

Akungba Akoko, Ondo State, Nigeria.

Emails:driakareem19 @gmail.com, ibraheem.kareem@aaua.edu.ng

Phone: +2348037010926 *Corresponding author

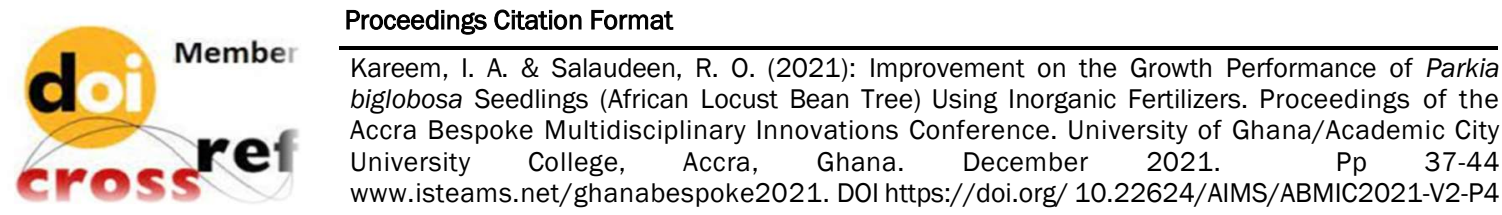




\title{
Improvement on the Growth Performance of Parkia biglobosa Seedlings (African Locust Bean Tree) Using Inorganic Fertilizers
}

\author{
Kareem, I. A. \& Salaudeen, R. 0.
}

\begin{abstract}
Parkia biglobosa (African locust bean tree) is one of the wild fruit trees in the savanna ecosystem and it is characterized with slow growth rate. The fruits are edible and very popular in western Nigeria and to some extent in other regions. Sequel to the slow growth rate of this plant, this study employed application of some inorganic fertilizers (Urea and N. P. K.) to possibly improve the growth rate of the seedlings of Parkia biglobosa. The design of the experiment is completely randomized design (CRD) consisting of three treatments and four replicates (treatment A: sandy loam + Parkia biglobosa seeds + N.P.K, B: sandy loam + Parkia biglobosa seeds + Urea and C: sandy loam + Parkia biglobosa seeds as control). The parameters investigated were seedlings' emergence rates and percentages and morphological growth parameters (plant height, leaf count, number of branches, collar girth and leaf area). Inorganic fertilizer application commenced 6 weeks after seedling emergence. The data collected were subjected to statistical analysis of variance which revealed significant differences $(P \leq 0.05)$ among the treatments. Treatment $B$ had the highest mean values, followed by $A$ and $C$ was the least. Thus, Urea and N.P.K fertilizers could be employed in improving the growth rate of this important tree species.
\end{abstract}

Keywords: Wild fruits, Parkia biglobosa, inorganic fertilizers, early growth rate, morphological, parameters.

\section{INTRODUCTION}

The African locust bean tree (Parkia biglobosa Jacq) is a perennial tree legume belonging to the family Fabaceae and subfamily Mimosoideae. Its origin had been traced to South America and due to its economic significance it had attracted more recognition (Joshi and Joshi, 2009; Laperia et al., 2014). It is a wild fruit tree which also helps in ensuring geo-ecological sustainability such as soil fertility, land improvement, erosion control and environmental air or atmosphere balance (Abebe et al., 2008).

As earlier observed by Ademola, et al. (2011), P. biglobosa seeds are processed into a condiment called 'iru' (in Yoruba - western Nigeria) or 'dawadawa' (in Hausa - northern Nigeria), which is a very good source of protein in Nigeria and other west African countries (e. g. Ghana). In fact, this wild fruit tree has numerous benefits and a blessing to Africa (Cemanskay, 2015). Thus, there is need to research on how to improve the growth rate of this important wild fruit tree and subsequently its yield. Eventually when its seedlings are planted on large scale especially under alley cropping system (an agro-forestry system) adequate soil conservation will be ensured on sustainable basis (Kareem and Ojo, 2019).

The objective of this study is to investigate the possibility of improving the growth rate of Parkia biglobosa seedlings through inorganic fertilizer application. 


\section{MATERIALS AND METHODS}

The experiment was carried out in the screen house of the Department of Plant Science and Biotechnology, Adekunle Ajasin University, Akungba -Akoko, Ondo State, Nigeria. The area (i. e. Ondo State) is characterized by two climatic seasons (the rainy season and dry seasons) and is on latitude of $7^{\circ} 28^{1} \mathrm{~N}$ and longitude of $50^{\circ} 44^{1}$. Experimental materials used include African locust bean (Parkia biglobosa) seeds, plastic buckets (perforated at the bottom), N.P.K. 15:15:15 and Urea fertilizers (procured from Ikare market, Ondo State), sandy loam/top soil used was gotten from the school premises. Other items used in collecting data on morphological indices include meter rule, thread, simple calculator, camera etc. The design of the experiment was completely randomized design (CRD) consisting of three treatments and four replicates. Table1 below shows the experimental plot layout:

.Table 1: Experimental Plot Layout

\begin{tabular}{|l|l|l|}
\hline A & B & C \\
\hline B & C & A \\
\hline C & A & B \\
\hline B & C & A \\
\hline
\end{tabular}

Legend: A - Sandy loam + Parkia biglobosa seeds, B - Sandy loam+ Parkia biglobosa seeds + Urea, C - Sandy loam+ Parkia biglobosa seeds (control)

Pertaining to the procedure, the perforated buckets were filled with sandy loam after proper identification and arranged in line with the design of the experiment which was completely randomized design (CRD) consisting of three treatments and four replicates, each of the replicates consisted of two units (later thinned to one), the soil used was taken to the laboratory for analysis (physicochemical analysis) to assess both the physical and chemical properties. The physical properties include the percentage sand, silt and clay while the chemical properties assessed were $\mathrm{pH}\left(\mathrm{H}_{2} \mathrm{O}\right)$, organic carbon, total nitrogen, available phosphorus, exchangeable bases: potassium, sodium, calcium, magnesium, aluminum, copper, manganese, zinc, exchangeable acidity and effective cation exchange capacity (ECEC).

The seeds of Parkia biglobosa were extracted from matured/ripe fruit, washed and air dried. Two seeds were sown at a depth of $2 \mathrm{~cm}$ in each bucket [though later thinned to one with better vigour at the $3^{\text {rd }}$ week after germination/seedling emergence (SE)] filled with sandy loam, watered twice daily (morning and evening). Germination/seedling emergence (SE) rates were taken daily and ended at $14^{\text {th }}$ day after sowing. The germination/SE percentages were calculated by dividing the number of seedlings that emerged by the total number of seeds sown and then multiplied by 100 . Morphological parameters such as plant height (measured by meter rule), number of leaves (by visual counting), collar girth (by placing thread round the basal part of the stem $2 \mathrm{~cm}$ from the ground level and later placed on the meter rule), number of branches (by visual counting) and the leaf area (measured by multiplying the length of each leaf by the mean breadth of the particular leaf at 3 points, then the average/mean area of 3 leaves on a seedling is used to multiply the total number of leaves on that particular seedling to obtain the area of all the leaves on that seedling). After 6 weeks of SE 1.8g of N.P.K 15:15:15 and Urea were applied using ring application method about $3 \mathrm{~cm}$ away from the seedlings at $2 \mathrm{~cm}$ depth and watered thrice a week. 
Data collection on morphological (growth) indices continued till the end of the experiment (at the $12^{\text {th }}$ week). Data were collected on soil physicochemical properties (by employing standard laboratory procedures), seedlings' emergence rates/percentages and morphological indices which include leaf count, collar girth, plant height, number of branches and leaf area. The parameters were analyzed by employing Analysis of Variance (ANOVA) technique (SPSS version 20.0)

\section{RESULTS}

The analyzed soil sample (sandy loam) indicated that the soil is made of three major physical components which are clay (20.20\%), sand (61.80\%) and silt (18.00\%). The chemical properties showed that the soil used consisted of total nitrogen (TN) of 4.35\%, $\mathrm{pH}\left(\mathrm{H}_{2} \mathrm{O}\right) 6.10$, Organic matter (42.60\%), available phosphorus $(36.67 \mathrm{ppm})$, exchangeable potassium $\left(0.41 \mathrm{~kg}^{-1}\right)$, exchangeable calcium $(0.29 \mathrm{mg} / \mathrm{kg})$, exchangeable Sodium $\left(0.52 \mathrm{~kg}^{-1}\right)$, exchangeable magnesium (2.16 kg-1), copper $\left(7.20 \mathrm{~kg}^{-1}\right)$,exchangeable acidity $\left(0.79 \mathrm{~kg}^{-1}\right)$ and $11.37 \mathrm{~kg}^{-1}$ for effective cation exchange capacity (ECEC).

With regards to the SE rate and percentages, total number of 48 seeds (scarified Parkia biglobosa seeds) were sown in sandy loam. Seedlings' emergence commenced on the $9^{\text {th }}$ and ended at the $14^{\text {th }}$ day after sowing.

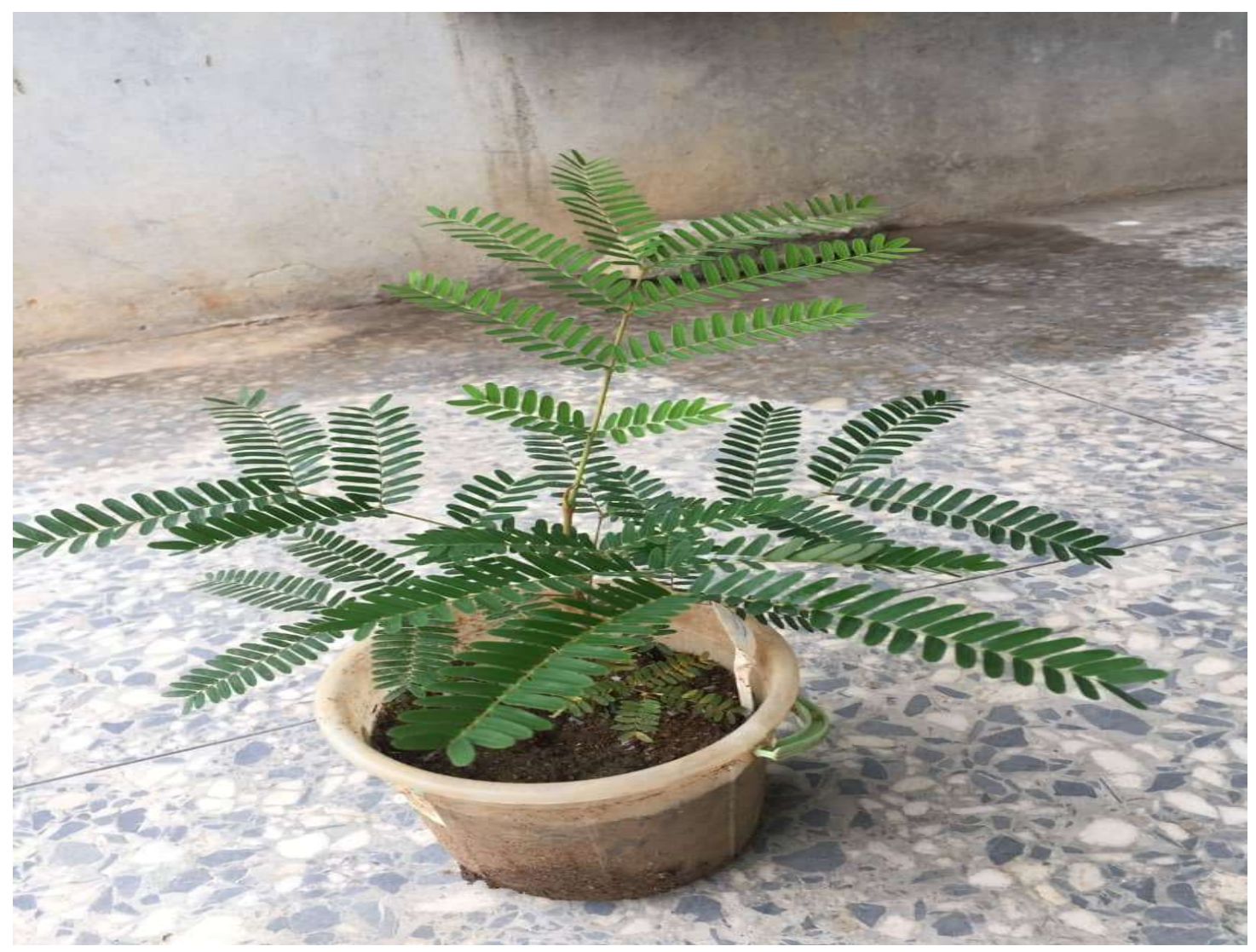

Plate1: Parkia biglobosa seedling 
There were significant differences in plant height among the treatments. The maximum mean value was observed in treatment $B(16.19 \mathrm{~cm})$ at week 12 followed by $A(12.63 \mathrm{~cm})$ and $C$ had the minimum mean value (Table2). Also, analysis of variance revealed that there were significant differences in leaf count. The observed maximum mean leaf count was recorded in treatment $B$ at week 12 with the highest mean value (35.63) followed by $A(28.25)$ and $C(27.75)$ had the least mean value (Table 2 below).

Table 2: Extract from statistical analysis on the values of some morphological parameters (weeks 6 and 12)

\begin{tabular}{|c|c|c|c|c|c|c|c|c|c|c|}
\hline TRT & PH6 & PH12 & LC6 & LC12 & NB 6 & NB B 12 & LA 6 & LA12 & CG6 & CG 12 \\
\hline $\mathrm{A}$ & \begin{tabular}{|l|}
9.05 \\
$\pm 1.31 \mathrm{a}$
\end{tabular} & $\begin{array}{l}12.63 \\
\pm 1.33 b\end{array}$ & $\begin{array}{l}16.75 \\
\pm 0.29 \mathrm{a}\end{array}$ & $\begin{array}{l}28.25 \\
\pm 5.98 \mathrm{a}\end{array}$ & $\begin{array}{l}4.38 \\
\pm 0.25^{a}\end{array}$ & $\begin{array}{l}7.13 \\
\pm 0.85^{b}\end{array}$ & $\begin{array}{l}111.55 \\
\pm 21.62^{a}\end{array}$ & \begin{tabular}{|l|}
294.94 \\
$\pm 78.71 \mathrm{a}$
\end{tabular} & $\begin{array}{l}1.41 \\
\pm 0.15 \mathrm{a}\end{array}$ & $\begin{array}{l}1.71 \\
\pm 0.15^{a}\end{array}$ \\
\hline$B$ & $\begin{array}{l}11.56 \\
\pm 1.40^{b}\end{array}$ & $\begin{array}{l}16.19 \\
\pm 0.97 \mathrm{c}\end{array}$ & $\begin{array}{l}20.25 \\
\pm 0.96 b\end{array}$ & $\begin{array}{l}35.63 \\
\pm 1.79 \mathrm{~b}\end{array}$ & $\begin{array}{l}5.25 \\
\pm 0.29 \mathrm{~b}\end{array}$ & $\begin{array}{l}7.88 \\
\pm 0.63^{c}\end{array}$ & $\begin{array}{l}179.78 \\
\pm 51.00^{b}\end{array}$ & $\begin{array}{l}532.98 \\
\pm 183.25 b\end{array}$ & $\begin{array}{l}1.56 \\
\pm 0.75^{a}\end{array}$ & $\begin{array}{l}2.03 \\
\pm 0.06^{b}\end{array}$ \\
\hline$C$ & $\begin{array}{l}9.63 \\
\pm 1.68^{a}\end{array}$ & $\begin{array}{l}12.46 \pm \\
1.40^{\mathrm{ab}}\end{array}$ & $\begin{array}{l}18.50 \\
\pm 2.79 \mathrm{ab}\end{array}$ & $\begin{array}{l}27.75 \\
\pm 4.73^{\mathrm{a}}\end{array}$ & $\begin{array}{l}4.88 \\
0.48^{\mathrm{ab}}\end{array}$ & $\begin{array}{l}7.00 \\
\pm 0.41^{\mathrm{a}}\end{array}$ & $\begin{array}{l}135.04 \\
\pm 40.25 \mathrm{ab}\end{array}$ & $\begin{array}{l}261.61 \\
\pm 120.64 \text { ab }\end{array}$ & $\begin{array}{l}1.51 \\
\pm 0.95^{a}\end{array}$ & $\begin{array}{l}1.70 \\
\pm 0.15^{\mathrm{a}}\end{array}$ \\
\hline GM & $\begin{array}{l}10.08 \\
\pm 1.74\end{array}$ & $\begin{array}{l}13.76 \\
\pm 2.12\end{array}$ & $\begin{array}{l}18.50 \\
\pm 2.15\end{array}$ & $\begin{array}{l}30.54 \\
\pm 5.56\end{array}$ & $\begin{array}{l}4.83 \\
\pm 0\end{array}$ & $\begin{array}{l}7.33 \\
\pm 0.72\end{array}$ & $\begin{array}{l}142.13 \\
\pm 46.39\end{array}$ & $\begin{array}{l}363.18 \\
\pm 175.35\end{array}$ & $\begin{array}{l}1.49 \\
\pm 0.12\end{array}$ & $\begin{array}{l}1.81 \\
\pm 0.19\end{array}$ \\
\hline
\end{tabular}

Legend: $\mathrm{PH}=$ Plant height $(\mathrm{cm}), \mathrm{N} \mathrm{B}=$ Number of branches, $\mathrm{LC}=$ Leaf count, LA = Leaf Area $\left(\mathrm{cm}^{2}\right)$, $\mathrm{CG}=$ Collar girth $(\mathrm{cm}), \mathrm{A}$ (Sandy loam +Parkia biglobosa seeds + N.P.K.), B (Sandy loam +Parkia biglobosa seeds + Urea), C (Sandy loam + Parkia biglobosa seeds).

In the table above, values that have different alphabets as superscripts are significantly different and values that have two different alphabets as superscript $\left(X^{\mathrm{ab}}\right)$ were different but not at significant level. Also values that have same alphabets as superscript are not significantly different (at $p<0.05)$.

The maximum mean leaf area was observed in treatment B (179.78) at weeks 6 while treatment $B$ had the highest mean value followed by $A$ and $C$ (the least mean value) at week 12 (532.98, 294.94 and 261.61 respectively, Table 2 above- values in $\mathrm{cm}^{2}$ ). At week 6 , the maximum number of branches were recorded in treatment $B(5.25)$ followed by $C(4.88)$ and $A(4.38)$ had the least mean number of branches. However, at week 12, B had the highest mean values followed by $A$ and $C$ had the least mean number of branches $(7.25,6.88,6.75$ and $7.88,7.13$ and 7.00 respectively). Analysis of variance revealed that there were significant differences in the collar girth among the treatments. The maximum mean values were observed in treatment $B$ followed by $C$ and $A$ had the least collar girth mean values at week 6 but at week 12 the highest mean values were recorded in treatment $B$ followed by $A$ and $C$ had the least collar girth mean values $(1.94,1.63,1.61$ and $2.03,1.71$ and 1.70 respectively, Table 2 above - values in $\mathrm{cm})$. 


\section{DISCUSSION}

This study showed a profound effect of the chemical fertilizers applied on the growth of Parkia biglobosa seedlings. It improved the nutrient status of the growth medium with significant differences (urea was better than NPK and control). It is also a well established fact that soil is very essential to the growth of crop plants in terms of development and yield especially when the soil is of reasonable nutrient status. Seedlings' emergence took place at the $9^{\text {th }}$ and ended at $14^{\text {th }}$ day after sowing (with 91.67 germination/seedling emergence percentage).

Early emergence observed was possibly due to removal of seed coat which has been eaten up by mechanical scarification or due to rasping of the seed hard coat which has eaten deeper to the epicarp or cotyledon which actually sped up the emergence or germination of the seeds as also confirmed by Agboola (2002). Tomlison et al. (2002) also reported that seed dormancy resulting from an impermeable seed coat could be overcome by peeling off seed coat. Several pre-sowing treatments such as scarification, hot water and acid treatment had been used and proven successful to overcome seed coat-imposed dormancy (Tekekay, 1996).

Analysis of variance (ANOVA) which indicated significant differences $(P<0.05)$ for all the morphological parameters (plant height, leaf count, number of branches, collar girth and leaf area) was due to the level of different nutrient/fertility statuses among the growth media. For instance, treatment B with urea in terms nitrogen was above others. This result was similar to that of Ashraf \& Rehman (1999) who reported that increasing supply of Urea (nitrogenous fertilizer) improved growth of corn.

Ashraf et al. (2002) and Gastal and Saugier (1986) submitted that urea application increased the number of leaves of plants and canopies to greater extent. Khalid et al. (2003) with regard to rice reported that plant growth was improved when nitrogen $(\mathrm{N})$, Potassium $(\mathrm{K})$ and Phosphorus (P) fertilizers were employed. Also, Kareem (2018) reported positive effects of NPK fertilizer on the growth and yield of Glycine max (soya bean).

Fertilizer application has been a major component of culture for over a century in Nigeria, since most of the arable lands are under continuous cultivation. Shifting cultivation as a land - use practice (where it exists) and the slash and burn system of land preparation practiced by the local farmers greatly deplete soil fertility. The best way of preventing soil from becoming poor is to put back into it what had been taken out and one of the ways to do this is through fertilizer application (Robert and Andrew, 1989), though should be at recommended rate (in $\mathrm{kg} / \mathrm{ha}$ ). Cooke (1972) reported that the major nutrients required by crops are nitrogen, phosphorus and potassium, inadequate supply of any of these nutrients during crop growth often leads to negative impact on the reproductive capacity, growth and yield of crops (Vine, 1953; Kareem and Adegoke, 2015) and supplementary amount of nutrients can be added to soil in form of inorganic fertilizer to correct inadequate supply of nutrient to crops. 


\section{CONCLUSION}

Growth of the Parkia biglobosa seedlings was enhanced positively during the period of study by the application of Urea, N.P.K. and even the sandy loam (Control). It could be vividly inferred that seeds of Parkia biglobosa mechanically scarified, sown in sandy loam and with the application of urea fertilizer was the most suitable for improving the growth rate of Parkia biglobosa. Thus, sandy loam could be used in sowing of seeds of Parkia biglobosa in order to achieve high germination/seedling emergence percentage and application of inorganic fertilizer (Urea, 6 weeks after germination/seedling emergence) could be used to improve the growth rate of seedlings of Parkia biglobosa. This can enhance the domestication and cultivation of this valuable plant in our environment on a very large scale for its edible seeds and soil improvement qualities (nitrogen fixiation activities).

\section{REFERENCES}

1. Abebe, M.; Oosting, S.; Fernandez, A.J; Vander, Z. (2008). Multipurpose fodder trees in the Ethiopian Highlands: farmers' preference and relationship of indigenous knowledge of feed value with laboratory indicators. Agric, Syst. 9, 184-194.

2. Ademola, I. T; Baiyewu, R.A; Adekunle, E. A; Omidiran, M. B. (2011). and proximate analysis of processed locust bean ( $P$. biglobosa) preserved with Common Salt. Pakistain journal of nutrition 10 (5): 405-408.

3. Agboola, O. 0; Basaranoglu, Z.; Yilmaz M., Bugutekin A., Full, M. Z. (2001). Physiochemical attributes of wine produced from the yellow pulp of Parkia biglobosa using traditional juice extraction techniques. Big. Food J. 19: 76-79.

4. Ashraf M., Rahman H. (1999). Interaction effects of nitrate and long term water logging on growth, water relations, and exchange properties of Maisie (Zea mays L) Plant Science. 144:35-43.

5. Ashraf, M.; Mustaq, M. A. and Missed A. (2002). Effect of sub and super-optimal nitrogen regimes on nutrient relation in two spring wheat cultivate differing in salinity tolerance. Floral, 197:126-133.

6. Cemansky, R. (2015). Africa's indigenous fruit trees: A blessing in decline. National Institute of Environmental Health Sciences, 123 (12), A291-A296.

7. Cooke, G.W. (1972). Fertilizer for maximum yield. Great Britain: Granada publishing Limited. 465pp.

8. Gastal F, saucier B (1986). Alimentation azoteeet Criossance de LA fetuque eleven. Assimilation du carboneet repartition entre organs Argro.6:157-166.

9. Joshi, A.R and Joshi, K. (2009).Plant Diversity and Ethno-botanical notes on tree species of Syabru Village, Langtang National park, Nepal. Ethno botanical leaflets 13: 651-64.

10. Kareem, I.A. and Adegoke, A. O.. (2015). Response of Glycine max (Soya Bean) to different levels of NPK fertilizer and Soil types. International Journal of Agric. Research and Review. 3(7): pp. 401-405.Spring Journals.

11. Kareem, I. A. (2018). Influence of soil manures (Organic and Inorganic) on the growth and yield of bell pepper (Capsicum annuum Linn.). Indian Journal of Applied Research. 8(9): pp. 11-13.

12. Kareem, I. A. and Ojo, M. O. (2019).Soil fertility status and crop yield as influenced by Albizia lebbeck benth (ratle tree) in alley cropping system. International Journal of Agric., Environment and Bioresearch.

13. Khalid M, Chaudhry FM, and H. (2003). Effect of different levels of N. P. K.On the yield and quality of Rice CV. IR-6 .J. Red.Science. 14:11-15. 
14. Lapeña, I., Turdieva, M., Noriega, I.L. and Ayad, W.G. (2014). Conservation of fruit tree diversity in Central Asia: Policy Options and Challenges. Biodiversity Inter-national, Rome, p. 251.

15. Robert, K. M and J. W. Andrew, (1989).An introduction to crop physiology. New York: Longman scientific and technical, Willey, 340.

16. Tekekay, D. (1996). Germination ecology of twelve indigenous species from Ethiopia. Forest ecology management 80: 209-223.

17. Tomlinson H, Ng'andwe M, Nikiema A. (2000). Field and invitro method of propagation of the African locust bean tree (Parkia biglobosa (Jacq) (Benth) J. hortic. Science.Biotechnol., 75.,42-49.

18. Vine, H. (1953).Experients in the maintenance of soil fertility in Ibadan, Nigeria. Empirical journal of experimental Agriculture.21:65-71. 